\title{
Shifting Eating Time Alters Rumen Dynamics in Once-daily Fed Dairy Cows
}

\begin{abstract}
Akbar Nikkhah
Rec date: Dec 19, 2015; Acc date: Dec 21, 2015; Pub date: Dec 22, 2015 distribution, and reproduction in any medium, provided the original author and source are credited.

Abstract

The objective was to establish effects of providing a total mixed ration (TMR) at either $0900 \mathrm{~h}$ or $2100 \mathrm{~h}$ on rumen fermentation and passage kinetics, and microbial protein biomass in lactating cows. Four multiparous and four primiparous Holstein cows were used in a crossover design study with two 6-week periods, each with 3-week adaptation. Total urine was collected during a sampling week in each period to measure urinary excretion of purine derivatives to estimate microbial protein biomass. Rumen ammonia concentrations were lower in primiparous cows fed at $2100 \mathrm{~h}$ vs. $0900 \mathrm{~h}(10 \mathrm{vs} .11 \mathrm{mg} / \mathrm{L}$, $\mathrm{P}<0.05)$. Rumen propionate was lower $(26.5$ vs. $28 \mathrm{mmol} / \mathrm{L})$ and the acetate to propionate ratio was higher (2.1 vs. 1.9$)$ in multiparous cow fed at $2100 \mathrm{~h}$ vs. $0900 \mathrm{~h}$. Microbial protein estimates were not significantly affected by eating time. Evening fed cows tended to realize a greater rumen volume than morning fed cows $(107$ vs. $90 \mathrm{~L}, \mathrm{P}<0.01)$. Therefore, feed delivery at $2100 \mathrm{~h}$ vs. $0900 \mathrm{~h}$ increased rumen volume and fermentation without significantly affecting microbial protein synthesis.
\end{abstract}

Chief Highly Distinguished Professor, Department of Animal Sciences, Faculty of Agricultural Sciences, University of Zanjan, Foremost Principal Highly Distinguished Scientist, National Elite Foundation, Iran

*Corresponding author: Akbar Nikkhah, Chief Highly Distinguished Professor, Department of Animal Sciences, Faculty of Agricultural Sciences, University of Zanjan, Foremost Principal Highly Distinguished Scientist, National Elite Foundation, Iran, Tel: +98-24-35052801; Fax: +98-24-35053202; E-mail: anikkha@yahoo.com

Copyright: $\odot 2015$ Nikkhah A. This is an open-access article distributed under the terms of the Creative Commons Attribution License, which permits unrestricted use,

Keywords: Feeding time; Evening eating; Rumen; Physiology; Holstein cow

\section{Introduction}

Most recently and in Latin square design studies with 14-d adaptation periods, feeding TMR at 2100 vs. $0900 \mathrm{~h}$ increased rumen digestion and milk fat yield [1]. The results have contributed to the emergence of a multiscience now known as "ruminant chronophysiological management", particularly related to the timing of eating [2,3]. The objective was to determine rumen fermentation indices and kinetics, and microbial protein synthesis estimates with 21$\mathrm{d}$ adaptation periods in response to feeding at $2100 \mathrm{~h}$ vs. $0900 \mathrm{~h}$.

\section{Materials and Methods}

Four multiparous ( $645 \pm 75 \mathrm{~kg}$ body weight; $77 \pm 25$ days in milk; mean \pm SD) and four primiparous (576 $\pm 46 \mathrm{~kg} \mathrm{BW} ; 90 \pm 33$ days in milk) lactating Holstein cows were monitored in a cross-over design experiment with two 42-d periods. Each period had 21-d of adaptation. Four cows were rumen-cannulated. Cows received a TMR with forage to concentrate ratio of 50.2:49.8 (DM basis) ad libitum for the entire experiment, permitting $5-10 \%$ orts. The average outside temperature and relative humidity during sampling weeks were $-3.7^{\circ} \mathrm{C}$ and $78.9 \%$, respectively. Lights were turned on at 03:45 just before morning milking, and were turned off at 22:45 h. Experimental treatments were feeding a TMR either at $0900 \mathrm{~h}$ or at $2100 \mathrm{~h}$. The forage portion of the TMR was a 50:50 mixture of alfalfa silage and barley silage.
Cows were milked twice daily at 0400 and $1600 \mathrm{~h}$ in their stalls. CoEDTA and Cr-mordanted alfalfa were used as the respective markers for measuring passage rates of rumen fluid and solids in the cannulated cows. Both markers were prepared according to Uden et al. [4].A total of $50 \mathrm{~g} \mathrm{Co-EDTA}$ was dissolved in $300 \mathrm{ml}$ of distilled water and infused into the rumen via the cannula at feed delivery. Simultaneously, $300 \mathrm{~g}$ of Cr-mordanted alfalfa was introduced into 10 different rumen sites. Rumen fluid and solids were sampled at 2, 3, 4, 6, $8,12,16,24,36,48$, and $72 \mathrm{~h}$ after marker introduction. The rumen markers concentrations were regressed against time using a first-order exponential equation to acquire passage rates (i.e., slopes) [5]. Rumen volume was calculated by dividing the infused amount of Co or Cr by the equation's intercept for individual cows.

Data were analyzed as linear MIXED MODELS [6]. For repeated rumen measures, models included additional fixed effects of sampling time, treatment $\times$ sampling time, parity $\times$ sampling time, and treatment $\times$ parity $\times$ sampling time. Effects of cow within parity and period were modeled as random. Least square means were estimated with the Restricted Maximum Likelihood (REML) method, and degrees of freedom were calculated using Satterwaith method [6]. Fixed effects were declared significant at $\mathrm{P}<0.05$, and trends were discussed at $0.05<\mathrm{P} \leq 0.10$. Results were reported as least square means \pm difference standard errors.

\section{Results}

Except for ammonia and molar percents of rumen propionate and 'acetate+butyrate' to propionate ratio, parity did not interact with feeding time on rumen fermentation indices. Time of feeding and parity did not affect $(\mathrm{P}=0.45)$ rumen $\mathrm{pH}$. Treatments did not affect rumen concentrations of total VFA, acetate, propionate, butyrate, isobutyrate, valerate, and lactate. The rumen concentration of isovalerate tended to be higher $(\mathrm{P}=0.09)$ for $0900 \mathrm{~h}$ than for $2100 \mathrm{~h}$ feeding. When expressed as molar proportions of total VFA, the 2100 $\mathrm{h}$-fed cows had higher $(\mathrm{P}=0.01)$ rumen acetate than the $0900 \mathrm{~h}$-fed cows. Rumen ammonia was lower $(\mathrm{P}<0.05)$ in $2100 \mathrm{~h}$-fed vs. $0900 \mathrm{~h}-$ fed primiparous cows, but not in multiparous cows. The $2100 \mathrm{~h}$-fed multiparous cows had lower rumen propionate $(\mathrm{P}<0.01)$ than their $0900 \mathrm{~h}$-fed peers. The acetate+butyrate to propionate ratio was higher $(\mathrm{P}<0.01)$ in multiparous cows fed at $2100 \mathrm{~h}$ vs. $0900 \mathrm{~h}$. Feeding time did not affect rumen fluid and solids retention times. Rumen volume tended to increase $(\mathrm{P}=0.07)$ by evening vs. morning feeding (Table 1$)$. Urinary purine derivatives and estimates of microbial protein synthesis were not significantly different (Table 1 ).

\begin{tabular}{|l|l|l|}
\hline & TF & P-value \\
\hline
\end{tabular}


Citation: Nikkhah A (2016) Shifting Eating Time Alters Rumen Dynamics in Once-daily Fed Dairy Cows. J Veterinar Sci Technol 7: e123. doi:

Page 2 of 2

\begin{tabular}{|l|l|l|l|l|l|l|}
\hline & $\mathbf{0 9 0 0 ~ h}$ & $\mathbf{2 1 0 0} \mathbf{h}$ & $\mathbf{S E M}$ & $\mathbf{T F}$ & $\begin{array}{l}\text { Parit } \\
\mathbf{y}\end{array}$ & $\begin{array}{l}\text { TF } \mathbf{x} \\
\mathbf{P}\end{array}$ \\
\hline Volume, L & 90 & 107 & 7.7 & $\begin{array}{l}0.0 \\
7\end{array}$ & 0.06 & 0.55 \\
\hline Fluid passage rate, \%/h & 11.9 & 11.7 & 0.5 & $\begin{array}{l}0.8 \\
1\end{array}$ & 0.35 & 0.67 \\
\hline Fluid retention time, h & 8.2 & 8.9 & 0.7 & $\begin{array}{l}0.3 \\
6\end{array}$ & 0.4 & 0.74 \\
\hline Solids passage rate \%/h & 3 & 3.3 & 0.1 & $\begin{array}{l}0.2 \\
1\end{array}$ & 0.52 & 0.04 \\
\hline Solids retention time, h & 33 & 31 & 1.8 & $\begin{array}{l}0.5 \\
2\end{array}$ & 0.53 & 0.11 \\
\hline Urinary uric acid, mmol/d & 52.8 & 48.6 & 2.23 & $\begin{array}{l}0.1 \\
2\end{array}$ & 0.43 & 0.15 \\
\hline Urinary allantoin, mmol/d & 454.6 & 421.4 & 28.9 & 0.3 & 0.34 & 0.57 \\
\hline Total PD, mmol/d & 507.3 & 470.1 & 28.34 & $\begin{array}{l}0.2 \\
4\end{array}$ & 0.34 & 0.48 \\
\hline Absorbed PD, mmol/d & 540.1 & 497.2 & 33.45 & $\begin{array}{l}0.2 \\
6\end{array}$ & 0.36 & 0.47 \\
\hline Microbial N synthesis, g/d & 392.6 & 361.5 & 24.36 & $\begin{array}{l}0.2 \\
6\end{array}$ & 0.35 & 0.47 \\
\hline
\end{tabular}

meal at 0030 vs. $0830 \mathrm{~h}$ ate more of it [7]. The decreased urinary $\mathrm{N}$ partitioning by evening feeding is in accordance with the lower rumen ammonia concentrations for the 2100 vs. $0900 \mathrm{~h}$ feeding.

\section{Conclusions}

Provision of a total mixed ration at $2100 \mathrm{~h}$ vs. $0900 \mathrm{~h}$ did not significantly affect urinary purine derivatives and estimates of duodenal microbial proteins. Rumen ammonia and propionate concentrations were lower and the acetate to propionate ratio was higher for cows fed at $2100 \mathrm{vs.} 0900 \mathrm{~h}$. The evening fed cows tended to have a greater rumen volume than the morning fed cows. Evening feeding increased milk fat and energy outputs. Findings establish timing of eating as a regulator of rumen kinetics and volume that is largely dependent on post-feeding intake patterns.

\section{Acknowledgments}

The supports of the Ministry of Science, Research and Technology, and National Elite Foundation are thanked.

\section{References}

1. Nikkhah A, Furedi CJ, Kennedy AD, Crow GH, Plaizier JC (2008) Effects of feed delivery time on feed intake, milk production, and blood metabolites of dairy cows. J Dairy Sci 91: 4249-4260.

2. Nikkhah A (2011) Eating timing an evolutionary manager of postmodern rumen physiology and health: a review. Open Access Anim Physiol 3: 1319.

Table 1: Time of feeding (TF) effects on rumen kinetics and urinary purine derivative $(\mathrm{PD})$ excretion and duodenal estimates of microbial protein.

\section{Discussion}

Increased rumen ammonia in morning vs. evening fed cows may suggest a more efficient $\mathrm{N}$ incorporation into microbial metabolism by evening feeding. The rumen fluid volume was increased whilst retention times were unaltered by evening feeding. These data were consistent with the increased nutrient intake within $3 \mathrm{~h}$ of feed delivery in $2100 \mathrm{~h}$-fed cows [3]. The current study for the first time uncovers the dependence of rumen kinetics on feeding time in lactating cows. The greater $\mathrm{N}$ intake of primiparous cows due to feeding at $2100 \mathrm{~h}$ was in agreement with Robinson et al. who found that cows fed a protein-

3. Nikkhah A (2012) Chronophysiology of ruminant feeding behavior and metabolism: an evolutionary review. Biol Rhythm Res 44: 197-218.

4. Moscardini S, Wright TC, Luimes PH, McBride BW, Susmel P (1998) Effects of rumen-undegradable protein and feed intake on purine derivative and urea nitrogen: Comparison with predictions from the Cornell Net Carbohydrate and Protein System. J Dairy Sci 81: 2421-2429.

5. Maekawa M, Beauchemin KA, Christensen DA (2002) Effect of concentrate level and feeding management on chewing activities, saliva production, ruminal pH of lactating dairy cows. J Dairy Sci 85: 1176-1182.

6. SAS Institute Inc (2003) SAS/STAT user's guide. SAS Institute Inc, Cary, NC 9: 1.

7. Robinson PH, Gill M, Kennelly JJ (1997) Influence of time of feeding a protein meal on ruminal fermentation and forestomach digestion in dairy cows. J Dairy Sci 80: 1366-1373. 